\title{
Keragaman dan Kelimpahan Nematoda secara Horizontal dan Vertikal pada Beberapa Tanaman Sayur di Kabupaten Cianjur
}

\author{
Muhammad Firdaus Oktafiyanto $^{1}{ }^{*}$, Roy Ibrahim $^{2}$ \\ ${ }^{1}$ Fakultas Pertanian Universitas Ibnu Chaldun Jakarta \\ ${ }^{2}$ Fakultas Pertanian Universitas Islam Negeri Sultan Syarif Kasim Riau \\ *Muhammadfirdausoktafiyanto@gmail.com
}

\begin{abstract}
Abstrak
Survei ini bertujuan untuk mengetahui keragaman dan kelimpahan nematoda pada beberapa tanman baik secara horizontal ataupun vertikal. Pengamatan secara horizontal yaitu dengan membandingan keragaman dan kelimpahan nemtoda pada tanaman woetel dengan polatanam yang berbeda yaitu monokultur dan polikultur. Sementara pengamatan secara vertikal dilakukan dengan membandingkan kelimpahan dan keragaman nematoda dari kedalaman tanah yang berbeda yaitu 0-10, 1020, dan 20-30 pada tanaman kubis dan tomat. survei ini dilaksanakan pada tanggal 22 November 2014, di Desa Sukatani, Kabupaten Cianjur Indonesia. Lokasi survei berada di ketinggian 1200 meter diatas permukaan laut, survey yang dilakukan menggunakan metode zig-zag, setiap pengambilan sampel diulang sebanyak tiga kali. Analisis laboratorium dilakukan dengan melakukan ekstraksi tanah yang diperoleh, lalu menghitung jumlah populasi nematoda yang diperoleh dibawah mikroskop. Hasil analisis menunjukan ada sebelas genus nemtoda yang diperoleh yaitu Rabditis sp., Pratylenchus sp., Helichotilenchus sp., Meloidogyne sp., Rotylenchus sp., Tylenchorynchus sp., Trichodorus sp., Criconemoides sp., Hoplolaimus sp., Dyctilenchus sp., dan Monochus sp. yang tersebar baik secara horizontal atau vertikal.
\end{abstract}

Kata kunci: Analisis Horizontal dan Vertikal, Wortel, Tomat, Kubis. Nematoda.

\section{Pendahuluan}

Cipanas merupakan salah satu daerah penghasil sayuran di jawa barat hasil produksi sayuran disalurkan untuk kebutuhan sayuran di daerah sekitarnya seperti Jabotabek, dijadikanya daerah cipanas menjadi sentra budidaya sayuran karena iklim untuk membudidayakan tanaman sayuran sangat cocok, kondisi lingkungan yang reatif dingin dengan penyinaran matahari yang cukup membuat tanaman sayur seperti tomat, kubis, dan wortel dapat ditanam disini.

Penggunaan lahan secara kontinyu dapat menyebabkan berkembangnya patogen, ditambah dengan cara tanaman yang digunakan adalah monokultur akan menyebabkan populasi patogen khususnya patogen tular tanah menjadi salah satu masalah di sana (Soesanto. 2013)

Salah satu patogen yang menjadi masalah di pertanaman sayuran adalah nematoda. Nematoda merupakan cacing mikroskopik yang dapat masuk kedalam jaringan tanaman dan menggang fungsi fisiologis dati tanaman tersebut (Mulyadi, 2009).

Terganggunya fungsi fisiologis tanaman menyebabkan berkurannya produksi dari tanaman sehingga menyebabkan kerugian secara ekonomis yang ditimbulkan oleh nematoda nilainya sangat besar Priece (2000), menyebutkan bahwa Kehilangan hasil akibat serangan nematoda di seluruh dunia dapat mencapai US\$ 80 milyar per tahun.

Nematoda juga menjadi salah satu penambah kerentanan tanaman karena nemtoda menjadi faktor predesposisi patogen lain, contohnya interaksi antara $R$. Solanacearum dengan nematoda puru akar
Meloidogyne incoqnita menambah keparahan penyakit layu bateri pada tanaman tomat (Priou et al. 2011).

Panggeso J (2010), mengatakan ketika serangan nematoda dapat diantisipasi maka kerugian dapat dihindari, salah satu cara mengantisipasi serangan nematoda yaitu melakukan analisis populasi pada lahan pertanian sebagai langkah/ tindakan preventif (pencegahan).

Pendapat diatas dapat dijadikan dasar dilakukannya analisis populasi nematoda yang kami lakukan. Analisis populasi nematoda ini bertujuan untuk mengetahui sebaran populasi nematoda yang ada secara horizontal (Poli-monokultur) pada wortel dan vertikal untuk membandingkan sebaran nematoda pada kedalaman yang berbeda, yaitu $0-10$, 10-20, 20-30 pada tanaman tomat dan kol.

Diharapkan dari hasil analisis keragaman populasi ini, kita dapat mengetahui jenis nematoda dari genus mana yang ada diperakaran tanaman. Hasil dari analisis ini dapat dijadikan patokan atau acuan untuk langkah pengendalian selanjutnya.

\section{Bahan dan Metode}

Survei dilaksanakan pada tanggal 28 November 2014 di lahan pertanian Desa Sukatani, Kabupaten Cianjur Indonesia. Lokasi survei berada di ketinggian 1200 meter diatas permukaan laut.Alat dan Bahan

Alat yang digunakan untuk menjalankan survei ini adalah bor tanah, plastik cerah, GPS, karet, kertas label, gunting, ember, saringan mesh dengan ukuran 2050 dan 500, centrifuge tube, gelas ukur, 
Centrifuge, botol koleksi, mikroskop compound, mikroskop stereo, cawan petri, pengkait nematoda, cawan sirakus, pipet, kaca preparat, cover glass, kamera, dan counter. Bahan yang digunakan untuk menjalankan survei ini adalah tanah sampel, air, dan larutan gula $40 \%$.

\section{Rancangan dan Pengambilan Sampel}

Sampel diambil dengan cara acak dengan metode zig-zag dengan menggunakan 3 ulangan, setiap ulangan diambil dari titik yang berbeda.

Lahan yang digunakan sebagai tempat pengambilan sampel tanah adalah lahan pertanaman wortel mono dan poli kultur, pemilihan lahan mono dan polikulter tersebut adalah untuk menngetahui sebaran nematoda secara horizontal. Tanaman lain yang diamati adalah lahan pertanaman kol dan tomat pada kedalam yang berbeda, yaitu 0-10, 10-20, 20-30 $\mathrm{cm}$.

\section{Ekstraksi Nematoda}

Ekstraksi nematoda dilakukan menggunakan metode Flotasi-Sentrifugasi. Tanah sampel diambil $100 \mathrm{ml}$ menggunakan gelas ukur, kemudian tanah dimasukkan kedalam wadah berisi $800 \mathrm{ml}$ air bersih dan didiamkan selama 20 detik. Cairan dituangkan melalui saringan bertingkat (20, 50, dan 500 mesh). Hasil penyaringan pada 500 mesh dimasukkan kedalam centrifuge tube, kemudian suspensi disentrifugasi selama 5 menit. Setelah disentrifugasi cairan dibuang dengan hati-hati hingga menyisakan endapan, kemudian endapan dicampur dengan gula $40 \%$ dan diaduk. Suspensi di sentrifugasi selama 1 menit, kemudian larutan gula berisi nematoda disaring dan dicuci dengan saringan 500 mesh. Hasil saringan dimasukkan dalam botol koleksi untuk dilakukan pengamatan.

\section{Perhitungan Populasi Nematoda}

Populasi nematoda dihitung dengan menuang suspensi hasil ekstraksi kedalam cawan sirakus lalu diamati dibawah mikroskop stereo dan compound dengan perbesaran $10 \times 10$.

Nematoda yang berhasil diekstrak kemudian disebar menggunakan pengkait nematoda dibawah mikroskop stereo dengan perbesaran 40x. Nematoda yang berhasil dikait diletakkan di atas kaca preparat yang telah ditetesi air, kemudian ditutup menggunakan cover glass. Nematoda diamati dibawah mikroskop compound dengan perbesaran 100 x 10. Morofologi yang diamati adalah: bibir, stilet, posisi esofagus terhadap usus, vulva, ekor, dan anulasi.

\section{Hasil Dan Pembahasan}

\section{Pengamatan Populasi Nematoda secara Horizontal}

Hasil pengamatan analisis populasi secara horizontal pada tanaman wortel menunjukkan terdapat perbedaan jumlah populasi antara, pengamatan pada sampel mono dan polikultur.

Hasil pengamatan populasi nematoda ada beberapa genus nematoda yang ditemukan seperti, Rabditis Sp., Pratyenchus sp., Helichotilenchus sp., Meloidogyne sp., Rotylenchus sp., Mononchus sp., Crichonemoides sp., dan Hoplolaimus sp.

Perbedaan populasi tersebut karena sistem atau pola tanaman yang digunakan sangat mempengaruhi keberadaan patogen di dalam suatu lingkungan. Lingkungan yang homogen akan menimbulkan berkembangnya patogen akibat makanan atau inang ketersediaannya sangat melimpah. Persentase hasil pengamatan menunjukan terdapat $64.1 \%$ nematoda pada lahan monokultur.

Hal tersebut berbeda dengan lahan yang ditanami secara polikultur. Lingkungan yang heterogen menyebabkan patogen lebih sulit untuk menimbulkan gejala karena inangnya terbatas atau dibatasi sehingga intensitas dan penyebaran penyakit lebih rendah. Persentase hasil pengamatan menunjukan terdapat $35.9 \%$ nematoda pada lahan polikultur.

Pendapat diatas sesuai dengan pendapat Rosya (2010), yang menyatakan Perkembangan nematoda cenderung lebih mudah terjadi pada pola tanam monokultur karena sumber makanan bagi nematoda selalu tersedia. Sebaliknya pada pola tanam polikultur yang diikuti dengan rotasi tanaman, dapat memutus siklus hidup nematoda termasuk nematoda. Pendapat yang sama dikemukakan oleh Koshy et al (2005), menyatakan bahwa pola tanam memiliki pengaruh besar dalam menentukan hubungan antara inang dan nematoda parasitik.

Berikut adalah tabel hasil pengamatan analisis populasi nematoda secara horizontal, pada tanaman wortel dengan pola tanam monokultur dan polikultur (Tumpangsari) (Tabel 1). 
Tabel 1 Pengamatan Nematoda pada tanaman wortel

\begin{tabular}{lrrrrrrrrr}
\multirow{2}{*}{ Nama } & \multicolumn{2}{c}{ Monokultur } & \multicolumn{2}{c}{ Polikultur } & Jumlah & PN(\%) \\
\cline { 2 - 8 } & 1 & 2 & 3 & 1 & 2 & 3 & & \\
\hline Rabditis & 2 & 1 & 0 & 0 & 0 & 0 & 3 & 5.66 \\
\hline Pratylechus & 2 & 0 & 1 & 0 & 1 & 1 & 5 & 9.434 \\
\hline Helicotilenchus & 0 & 0 & 0 & 0 & 0 & 2 & 2 & 3.774 \\
\hline Meloidogyne & 4 & 3 & 3 & 1 & 3 & 3 & 17 & 32.08 \\
\hline Rotylenchus & 6 & 5 & 5 & 2 & 3 & 0 & 21 & 39.62 \\
\hline Mononchus & 0 & 1 & 0 & 1 & 0 & 0 & 2 & 3.774 \\
\hline Criconomoides & 0 & 0 & 1 & 0 & 1 & 0 & 2 & 3.774 \\
\hline Hoplolaimus & 0 & 0 & 0 & 1 & 0 & 0 & 1 & 1.887 \\
\hline Jumlah & 14 & 10 & 10 & 5 & 8 & 6 & 53 & \\
\hline PU (\%) & 26.415 & 18.87 & 18.87 & 9.43396 & 15.094 & 11.32 & & \\
\hline
\end{tabular}

Keterangan : PU = Presemtasi ulangan(Presentasi dari nematoda yang diperoleh pada setiap ulangan di bagi total nematoda). $\mathrm{PN}=$ Presentasi Nematoda (Jumlah nematoda yang muncul pada semua pengamatan di bagi dengan total nematoda)

Hasil pengamatan diatas menunjukan bahwa ada beberapa genus nematoda yang memiliki populasi yang tinggi. Contohnya pengamatan pada genus Meloidogyne sp. persentasenya nematodanya sebesar $32.08 \%$, dan pada genus Rotylenchus sp. persentasenya $39.62 \%$. Kedua nematoda tersebut adalah nematoda yang paling medominasi pada pertanaman wortel baik poliuktur maupun monokultur.

Nematoda dengan jumlah tertinggi pada pengamatan ini adalah Rotylenchus sp. nematoda ini juga merupakan menjadikan wortel sebagai inangnya. Tanaman wortel yang terserang biasanya akan mengalami kelainan pada pertumbuhannya, yaitu umbi akan menjadi lebih kecil dibandingkan tanaman yang sehat, selain itu juga ukurannya menjadi lebih kecil dengan rambut akar disekitar umbinya (Seinhorst dan Kuniyasu. 1968)

Nematoda ini dapat berkembang sangat pesat, dengan intensitas serangan yang tinggi

jika tanaman wortel ditanam pada tanah yang berpasir, karena pada tanah berpasir rongga pori tanah yang lebih renggang akan memudahkan nematoda untuk bergerak, sehingga pergerakan semakin jauh (Seinhorst dan Riezebos. 1959)

Nematoda selanjutnya dengan populasi tertinggi adalah genus Meloidogyne sp. populasi Meloodogyne yang tinggi dapat disebabkan oleh, genus Meloidogyne ini merupakan salah satu nematoda yang memiliki kisaran inang yang sangat luas tercatat bahwa terdapat menyerang \pm 2000 species tanaman: pangan, sayuran, hias, berkayu / pohon, dll. (Adnan, 2000). Distribusi merata di seluruh dunia: daerah tropika, subtropika, dan beriklim sedang. Jumlah spesiesnya mencapai 60 spesies dengan 4 nematoda utama yaitu $M$. hapla, $M$. incognita, $M$. javanica, $M$. arenaria.(Dropkin, 1991)

Jumlah persentase yang tinggi juga disebabkan oleh tanaman wortel yang merupakan inang dari tanamn wortel. Hasil penelitian Kurniawan (2010) membuktikan

penyebab utama penyakit umbi bercabang pada wortel di daerah Jawa Barat ialah NPA. Kehilangan hasil akibat penyakit ini mencapai antara 5\% dan 95\%.

Hasil pengamatan diatas juga menunjukan selain adanya nematoda parasit tumbuhan ternyata, ada beberapa nematoda yang bersifat predator yang ditemui diantaranya genus Rabditis sp., dan Mononchus sp. tapi jumlahnya sedikit. Keberadaan nematoda predator ini termasuk dalam salah satu pengendalian hayati yang dapat digolongkan sebagai hiperparasitisme untuk menekan pertumbuhan nematoda. Menurut Altieri dan Nicholls (2004) kombinasi tanaman yang sesuai pada pola tanam akan meningkatkan keragaman mikroorganisme dalam tanah. Selain itu menciptakan keseimbangan ekosistem dan menstimulasi kehadiran agens hayati.

\section{Pengamatan Populasi Nematoda Secara Vertikal.}

Pengamatan nematoda secara vertikal ini dilakukan untuk mengetahui sebaran nematoda pada kedalaman tanah yang berbeda.

Hasil pengamatan menunjukan bahwa ternyata perbedaan kedalaman tanah mulai dar 0-10, 10-20, 
dan 20-30 berpengaruh terhadap jumlah nematoda yang diperoleh.

Tanah yang diambil di dekat perakaran tanaman terdapat jumlah nematoda yang lebih banyak, karena serangan nematoda berada pada sekitar perakaran.

Selain kedalaman tanah yang diambil ternyata kedalaman perakaran juga sangat mempengaruhi populasi nematoda. Karena perakaran tanaman mengeluarkan eksudat yang dikenali oleh inang, eksudat tersebut memacu nematoda untuk mendekat dan memarasit. Contohnya tanaman kentang memiliki eksudat akar yang khas, eksudat akar tersebut dijadikan sinyal untuk aktifnya nematoda Globodera sp. Sista nematoda sista kentang yang disebabkan oleh Globodera sp. hanya aktif ketika ada tanaman kentang, dan ketika tidak ada tanaman kentang maka sista dari Globodera sp. tidak akan aktif (Mulyadi, 2009).

Hasil pengamatan populasi nematoda secara vertikal ini memperoleh sepuluh genus nematoda, diantaranya Rabditis sp., Pratylenchus sp., Helichotilenchus sp., Meloidogyne sp., Rotylenchus sp., Tylenchorynchus sp., Trichodorus sp., Criconemoides sp., Hoplolaimus sp., Dyctilenchus sp., dan Monochus sp. nematoda diatas selain bersifat parasit ada beberapa nematoda yang bersifat nonparasit yaitu sebagai predator.

Berikut ini adalah data hasil analisis populasi secara vertikal pada pertanaman tomat dan kubis (Tabel 2) 
Tabel 2 Pengamatan Nematoda pada tanaman tomat dan kol dibeberapa kedalaman tanah

\begin{tabular}{|c|c|c|c|c|c|c|c|c|c|c|c|c|c|c|c|c|c|c|c|c|}
\hline \multirow{3}{*}{ Nama } & \multicolumn{9}{|c|}{ Tomat } & \multicolumn{9}{|c|}{ Kubis } & \multirow[t]{2}{*}{ Jumlah } & \multirow[t]{3}{*}{$\mathrm{PN}(\%)$} \\
\hline & \multicolumn{3}{|c|}{$\begin{array}{c}\text { Kedalaman } \\
0-10 \mathrm{~cm} \\
\end{array}$} & \multicolumn{3}{|c|}{$\begin{array}{c}\text { Kedalaman } \\
10-20 \mathrm{~cm}\end{array}$} & \multicolumn{3}{|c|}{$\begin{array}{c}\text { Kedalaman } \\
20-30 \mathrm{~cm}\end{array}$} & \multicolumn{3}{|c|}{$\begin{array}{c}\text { Ke dalaman } \\
0-10 \mathrm{~cm}\end{array}$} & \multicolumn{3}{|c|}{$\begin{array}{c}\text { Ke dalaman } \\
10-20 \mathrm{~cm} \\
\end{array}$} & \multicolumn{3}{|c|}{$\begin{array}{c}\text { Ke dalaman } \\
20-30 \mathrm{~cm}\end{array}$} & & \\
\hline & 1 & 2 & 3 & 1 & 2 & 3 & 1 & 2 & 3 & 1 & 2 & 3 & 1 & 2 & 3 & 1 & 2 & 3 & & \\
\hline Rabditis & 1 & 2 & 1 & 2 & 1 & 0 & 2 & 1 & 0 & 2 & 0 & 0 & 2 & 1 & 1 & 1 & 0 & 0 & 17 & 8.46 \\
\hline Pratylechus & 4 & 1 & 0 & 8 & 5 & 2 & 1 & 0 & 1 & 7 & 7 & 8 & 4 & 2 & 2 & 2 & 2 & 1 & 57 & 28.36 \\
\hline Helicotilenchus & 0 & 1 & 2 & 1 & 2 & 3 & 2 & 1 & 0 & 5 & 2 & 4 & 6 & 0 & 2 & 0 & 0 & 0 & 31 & 15.42 \\
\hline Meloidogyne & 2 & 3 & 1 & 12 & 5 & 8 & 2 & 2 & 1 & 0 & 0 & 0 & 0 & 0 & 0 & 0 & 0 & 0 & 36 & 17.91 \\
\hline Rotilenchus & 1 & 1 & 6 & 3 & 6 & 2 & 1 & 3 & 1 & 0 & 0 & 0 & 0 & 0 & 0 & 0 & 0 & 0 & 24 & 11.94 \\
\hline Tylenchorynchus & 0 & 0 & 0 & 0 & 0 & 0 & 0 & 0 & 0 & 2 & 1 & 1 & 0 & 1 & 0 & 0 & 0 & 0 & 5 & 2.49 \\
\hline Trichodorus & 0 & 0 & 0 & 0 & 0 & 0 & 0 & 0 & 0 & 2 & 1 & 1 & 0 & 0 & 0 & 0 & 0 & 0 & 4 & 1.99 \\
\hline Criconomoides & 0 & 0 & 0 & 0 & 0 & 0 & 0 & 0 & 0 & 2 & 2 & 0 & 3 & 2 & 1 & 2 & 0 & 0 & 12 & 5.97 \\
\hline Hoplolaimus & 0 & 0 & 0 & 0 & 0 & 0 & 0 & 0 & 0 & 1 & 0 & 2 & 1 & 0 & 2 & 0 & 0 & 0 & 6 & 2.99 \\
\hline Dyctilenchus & 0 & 0 & 0 & 0 & 0 & 0 & 0 & 0 & 0 & 0 & 3 & 2 & 0 & 0 & 0 & 0 & 2 & 1 & 8 & 3.98 \\
\hline Monochus & 0 & 0 & 0 & 0 & 0 & 0 & 0 & 0 & 0 & 0 & 0 & 0 & 0 & 0 & 0 & 1 & 0 & 0 & 1 & 0.50 \\
\hline Jumlah & 8 & 8 & 10 & 26 & 19 & 15 & 8 & 7 & 3 & 21 & 16 & 18 & 16 & 6 & 8 & 6 & 4 & 2 & 201 & \\
\hline PU (\%) & 3.98 & 3.98 & 4.98 & 12.94 & 9.45 & 7.46 & 3.98 & 3.48 & 1.49 & 10.45 & 7.96 & 8.96 & 7.96 & 2.99 & 3.98 & 2.99 & 1.99 & 1.00 & & \\
\hline
\end{tabular}

Keterangan : PU = Presemtasi ulangan(Presentasi dari nematoda yang diperoleh pada setiap ulangan di bagi total nematoda). PN= Presentasi Nematoda (Jumlah nematoda yang muncul pada semua pengamatan di bagi dengan total nematoda) 
Hasil analisis populasi diatas menunjukan bahwa terjadi perbedaaan jumlah genus nematoda pada pertanaman tomat dan kubis, pertanaman kubis memiliki jumlah genus yang lebih banyak dibandingkan dengan pertanaman tomat.

Pengamatan pada pertanaman kubis menyatakan bahwa terdapat sembilan genus nematoda tapi jumlahnya untuk setiap genus relatif lebih sedikit dibandingkan dengan tanaman tomat, pada tanaman tomat jumlah nematoda untuk spesies Meloidogyne sp. adalah nematoda dengan populasi terbanyak karena pertanaman tomat merupakan salah satu inang dari nematoda khususnya Meloidogyne sp. (Semangun. 2007)

Selain itu Meloidogyne sp. juga merupakan nematoda dengan cakupan inang yang luas atau sering disebut kosmopolit, dan nematoda dinegara tropik biasanya lebih sulit untuk dikendalikan populasinya karena tidak terdapat musim dingin yang dapat mematikan mikroba tanah salah satunya nematoda. Pendapat tersebut sesuai dengan pernyataan Luc et al. (1995) menyatakan bahwa spesies nematoda parasit yang paling banyak di daerah tropik dengan zona iklim panas dan lembap, baik pada dataran rendah dan dataran tinggi, ialah Meloidogyne.

Perhitungan PU pada tabel diatas dapat digunakan untuk melihat persentase sebaran nematoda berdasarkan kedalaman pengambilan tanah. terlihat pada tanah pertanaman tomat yang diambil pada kedalaman $10-20 \mathrm{~cm}$ memiliki populasi nematoda tertinggi yaitu $29,81 \%$ dari keseluruhan populasi nematoda, sementara populasi terrendah adalah saat pengambilan sampel pada kedalaman 20$30 \mathrm{~cm}$. Pengambilan sampel pada perakaran tanaman kubis terdapat persentase populasi tertinggi pada kedalaman $0-10 \mathrm{~cm}$ yaitu sebesar $27.34 \%$ dari keseluruhan nematoda, sementara persenase nematoda yang terrendah adalah pada pengambilan sampel pada kedalaman 20-30.

Hal tersebut karena sebaran nematoda dan dalamnya akar tanaman, artinya pada tanaman tomat di kedalaman tanah pada dasarnya adalah mengikuti sebaran dari akar tanaman, nematoda biasnya akan mendekati akar tanaman yang sedang aktif mengeluarkan eksudat, karena salah satu dari sinyal yang diberikan nematoda adlah eksudat, dan nematoda memiliki reseptor untuk mendekati bagian akar tanaman tersebut, itu dilakukan untuk mengefisienkan pergerakan dari nematoda (Mulyadi, 2009)

Persentase nematoda dengan jumlah tertinggi pada persentasi nematoda terdapat pada nematoda dari genus Pratylencus sp. yaitu sebesar $28.36 \%$, selain pada tanaman tomat dan kubis ternyata nematoda ini juga di temukan pada pengamatan pertanaman wortel baik dengan pola tanaman monokultur ataupun polikultur tapi jumlahnya tidak sebanyak pada pertanaman kol dan kubis.
Nematoda Pratylenchus merupakan nematoda parasit penting kedua setelah meloidogyne, terdapat 55 spesies yang tersebar luas di seluruh dunia. Nematoda ini juga dapat menyerang berbagai jenis tanaman seperti tanaman tahunan, Hortikultur, serealia, perkebunan, pangan, dan kehutanan. Pratylenchus merupakan salah satu nematoda endoparasit berpindah dalam akar atau bagian tanaman lain seperti umbi, stolon dan rizoma dll. (Castillo dan Vovlas. 2007).

Gejala serangan dari nematoda Pratylenchus yaitu terjadi pada bagian bawah tanaman, seperti timbulnya lesioatau luka berbentuk bulat atau tidak beraturan, berwarna cerah kemudian membesar, berwarna gelap dan nekrotik (Dropkin, 1991).

Selain nematoda parasit ternnyata pada pengambilan contoh nematoda pada beberapa kedalaman ditemukan nematoda non parasit seperti Mononchus dan Rabditis

\section{Kesimpulan}

Bedasarkan hasil analisis populasi secara Horizontal terdapat sembilan gens nematoda yaitu : Rabditis Sp., Pratyenchus sp., Helichotilenchus sp., Meloidogyne sp., Rotylenchus sp., Mononchus sp., Crichonemoides sp., dan Hoplolaimus sp. dari nematoda diatas Rotylenchus dan Meloidogyne memilike persentase populasi tertinggi yaitu $39.62 \%$. dan $32.08 \%$,

Sementara pada pengamatan secaraVerikal ditemukan sebeas genus nemtatda yaitu : Rabditis sp., Pratylenchus sp., Helichotilenchus sp., Meloidogyne sp., Rotylenchus sp., Tylenchorynchus sp., Trichodorus sp., Criconemoides sp., Hoplolaimus sp., Dyctilenchus sp., dan Monochus sp. nematoda Pratylenchus memiliki populasi tertinggi pada pengmatan ini yaitu 26,38 .

Ada bebrtapa nematoda yang bersifat komopolit, yaitu Meloidogyne dan Pratylenchus karena populasinya relatif lebih tinggi pada tanama-tanaman yang diamati.

\section{Dafar Pustaka}

Adnan AM. 2000. Ketahanan beberapa varietas kedelai terhadap nematoda puru akar (Meloidogyne incognita). Bulletin of Plant Pests and Diseases. 12(1):11-16.

Altieri AA, Nicholls CL. 2004. Biodiversity and Pest Management in Agroecosystems. Food Products Press. New York (US). Hlm 236243.

Castillo. P dan N. Vovlas. 2007. Nematology Monographs and Perspective Pratylenchus 
Diagnosis, Biology, Patogenicity and Management. Brill. Netherlands

Dropkin VH. 1991. Pengantar Nematologi Tumbuhan. Gadjahmada University Press. Yogyakarta.

Kurniawan W. 2010. Identifikasi penyakit umbi bercabang pada wortel, Daucus carota (L.) di Indonesia [tesis]. Bogor (ID): Institut Pertanian Bogor.

Luc MRA, Sikora T, Bridge. 1995. Nematoda Parasit Tumbuhan di Pertanian Sub Tropik dan Tropik. Supratoyo, penerjemah; Yogyakarta (ID): Gadjah Mada Univ. Terjemahan dari: Plant Parasitic Nematology in Tropic and Sub Tropic.

Mulyadi. 2009. Nematologi Pertanian. Gadjahmada University Press. Yogyakarta.

Panggeso, Johanis. 2010. Analisis Kerapatan Populasi Nematoda Parasitik Pada Tanaman Tomat (Lycopersicum esculentum Mill.) Asal Kabupaten Biromaru. Agroland 17 (3):198204.

Price, T.V. 2000. Plant-parasitic nematodes. Integrated Pest Management for SmallholderEstate Crops Project. Plant Quarantine Component - Nematology. p. 2734. Pepper. Piper nigrum. Medicinal And
Aromatic Plants - Industrial Profiles. Harwood Academic Publishers. p 297-308.

Priou, S., P. Alley, E. Chujoy, B. Lemaga and E.R. French. 2011. Integrated Control of bacterial wilt of potato. (On-line). http://www.fao.org/sd/erp/ toolkit/BOOKS/integrated_control_of bacteria 1 wilt in potato.pdf. diakses pada 15 Desember 2014

Rosya, A. 2013. Keragaman Komunitas Fitonematoda pada Sayuran Lahan Monokultur dan Polikultur di Sumatra Barat. JFI (9) 71-76

Seinhorst J.W, dan K. Kuniyasu. 1968. Rotylenchus Uniformis (Thorne) on Charrots. Neth. J. PI. Path. 75(1969) 205- 223

Seinhorst, J. W. dan Riezebos, D., 1959: Trials on the control of staartpeen tailed carrot disease. Meded. Dir. Tuinb, 22: 620-625.

Semangun, H., 2007. Penyakit-penyakit Tanaman Hortikultura Di Indonesia, Gadjah Mada University Press, Yogjakarta,

Soesanto L, Ruth Feti Rahayuniati. 2013. Penyakit Karena Bakteri, Virus, Nematoda, dan Kahat hara - Kompedium Pnyakit-Penyakit Kacang Tanah. Graha Ilmu:Yogyakarta 